\title{
FIELD TESTING OF TOMATO CHILLING TOLERANCE UNDER VARYING LIGHT AND TEMPERATURE CONDITIONS
}

\author{
Rafael Elizondo ${ }^{1}$, and Eduardo Oyanedel ${ }^{1^{*}}$
}

\begin{abstract}
Chilling tolerance is a desirable trait in commercial tomato varieties, in order to extend the growing season and geographic range. Two Nearly Isogenic Lines (NILs) with introgressions in chromosome 2 and 3 of Solanum habrochaites S. Knapp \& D.M. Spooner, a cold-resistant wild tomato, were evaluated in the field. Four plantings were established between 21 August and 2 October 2006 (day 232 and 274). Throughout the experiment the heat sum was interpreted using air temperature to calculate growing degree days (base $12{ }^{\circ} \mathrm{C}$ ) and chilling hours (below $12^{\circ} \mathrm{C}$ ), with the daily light integral calculated as global solar radiation. The relative post-transplant growth rate, fruit set and yield, were evaluated over two successive 10-d periods. Chilling tolerance is expressed under high radiation and low temperature conditions, which occurred during the 10-d post-transplant evaluation period beginning on day 257, when both NILs achieved a leaf area growth rate 1.7 times higher than the control plants. During the second evaluation period, 10-20 d post-transplant, both NILs grew on average, 1.4 times more than the control. There were no significant differences in earliness or fruit set. These NILs should not be used as a direct source to obtain chilling tolerant varieties, because of the low fruit set, 84\% lower in LA3921 than the control, probably due to linkage drag and poor environmental adaptability in both lines.
\end{abstract}

Key words: Linkage drag, Solanum habrochaites, NILs.

\section{INTRODUCTION}

The cultivated tomato genotype (Solanum lycopersicum L.) displays limited growth and development at temperatures under $12{ }^{\circ} \mathrm{C}$ (Hu et al., 2006). At temperatures between 0 and $12{ }^{\circ} \mathrm{C}$, plants are damaged by chilling stress. The severity of damage is proportional to the length of time spent in this temperature range, with alterations in flowering (Adams et al, 2001), germination (Foolad and Lin, 2000), cellular turgor (Bloom et al., 2004); nutrient absorption (Bloom et al., 1998) and photoinhibition of photosynthesis (Venema et al., 2000).

Due to their sensitivity to cold, commercial cultivated tomatoes are planted in the field at later dates to avoid excessively low temperatures and minimize the risk of chilling damage. Cold resistant cultivars could be planted earlier in the season leading to an earlier harvest. This would provide greater efficiency in the use of installed processing capacity (Foolad and Lin, 2000).

${ }^{1}$ Pontificia Universidad Católica de Valparaíso, Facultad de Agronomía, Casilla 4-D, Quillota, Chile. *Corresponding author (eoyanede@ucv.cl).

Received: 21 December 2009.

Accepted: 28 April 2010.
Unlike cultivated tomatoes, wild tomato species such as $S$. habrochaites S. Knapp \& D.M. Spooner, S. chilense (Dunal) Reiche and S. peruvianum L., recover rapidly after exposure to sub-optimal temperatures, which is expressed through greater growth capacity and decreased inhibition of photosynthesis (Brüggemann and Linger, 1994) or minor alterations in $\mathrm{N}$ metabolism (Jones et al., 1998). Wild species have been used for constructing genetic maps and identifying genes of agronomic importance.

Through backcrosses and selection assisted by molecular markers, cold resistant genes from wild species can be bred into cultivated tomato varieties (Goodstal et al., 2005). Cold resistant quantitative trait loci (QTLs) have been identified in accession LA 1777 of $S$. habrochaites (Oyanedel et al., 2001).

Nearly isogenic lines (NILs) contain introgressions in a defined region of the genome and are obtained through backcrosses and marker-assisted selection. NILs have been used to study and isolate genes responsible for different agronomic traits. NILs allow for studying the behavior of specific genomic regions, offering an alternative to classic strategies of mapping based on $F_{2}$ populations. $F_{2}$ mapping populations are ephemeral, while those of NILs are permanent. This facilitates the identification of QTLs in multi-year studies in various localities. However, it 
requires more time to form a NIL population than an $\mathrm{F}_{2}$. NILs express different characteristics among themselves through their allelic combination and are developed to study genes involved in morphogenesis and metabolic regulation, as well as to introduce new genetic variability in germplasm of interest (Monforte and Tanksley, 2000).

The hypothesis of this study is that the chillingresistant NILs LA3921 and LA3925 can grow under field conditions when transplanted early. These NILs have demonstrated cold resistance under laboratory conditions, showing promise for use in improvement programs (Oyanedel et al., 2001). The objectives of this study were (1) to evaluate the productive behavior of lines with cold resistance at early planting dates, and in full season, for the Quillota area; and (2) to verify the expression of cold resistance and determine the combinations of environmental factors that provoke this response.

\section{MATERIALS AND METHODS}

The two NILs used were derived from an inter-species crossing of the cold-tolerant wild species Solanum habrochaites f. typicum accession LA1777 with the tomato inbred E6203, used to develop processing varieties (Monforte and Tanksley, 2000). The seeds were provided by the C.M. Rick Genetics Resource Center, Davis, California, USA.

The study took place at the La Palma Experimental Station in Quillota (32 53 ' S, $71^{\circ} 12^{\prime}$ W) between August 2006 and February 2007. A soil saturation extract yielded: pH 7.9; electrical conductivity $0.53 \mathrm{mS} \mathrm{cm}^{-1}$; organic matter $2.6 \%$, available $\mathrm{N} 14.8 \mathrm{mg} \mathrm{kg}^{-1}$, available $\mathrm{P} 76 \mathrm{mg}$ $\mathrm{kg}^{-1}$, exchangeable K $242 \mathrm{mg} \mathrm{kg}^{-1}$, exchangeable Ca 10.6 $\mathrm{cmol} \mathrm{kg}^{-1}$, and exchangeable $\mathrm{Mg} 2.92 \mathrm{cmol} \mathrm{kg}^{-1}$. Drip irrigation tapes $\left(5 \mathrm{~L} \mathrm{~m}^{-1} \mathrm{~h}^{-1}\right)$ were used, providing 20 to $40 \mathrm{~m}^{3} \mathrm{ha}^{-1}$ at each irrigation event. The crop was watered when the tension $20 \mathrm{~cm}$ below an emission point was 0.15 $\mathrm{kg} \mathrm{cm}{ }^{-2}$.

The treatments were: $\mathrm{T} 0$ : the processing tomato inbred E6203 as an isogenic control; T1: NIL LA3921 with an introgression on chromosome 2, between CT9 and CT140, a region where a recessive QTL that increases dry matter accumulation during cold stress (Figure 1) was identified; T2: NIL LA3925 with an introgression on chromosome 3, between TG359 and TG366, a region in which a dominant QTL that increases dry matter during cold stress was identified (Oyanedel, 2000). The acronyms TG and CT are the initials of the authors of the molecular markers in the reference map (Grandillo and Tanksley, 1996).

Transplants were produced in a commercial nursery, using three true leaves as a transplant index. The crop was established at 2-wk intervals, with three early planting dates and a mid-season control. These dates were
2
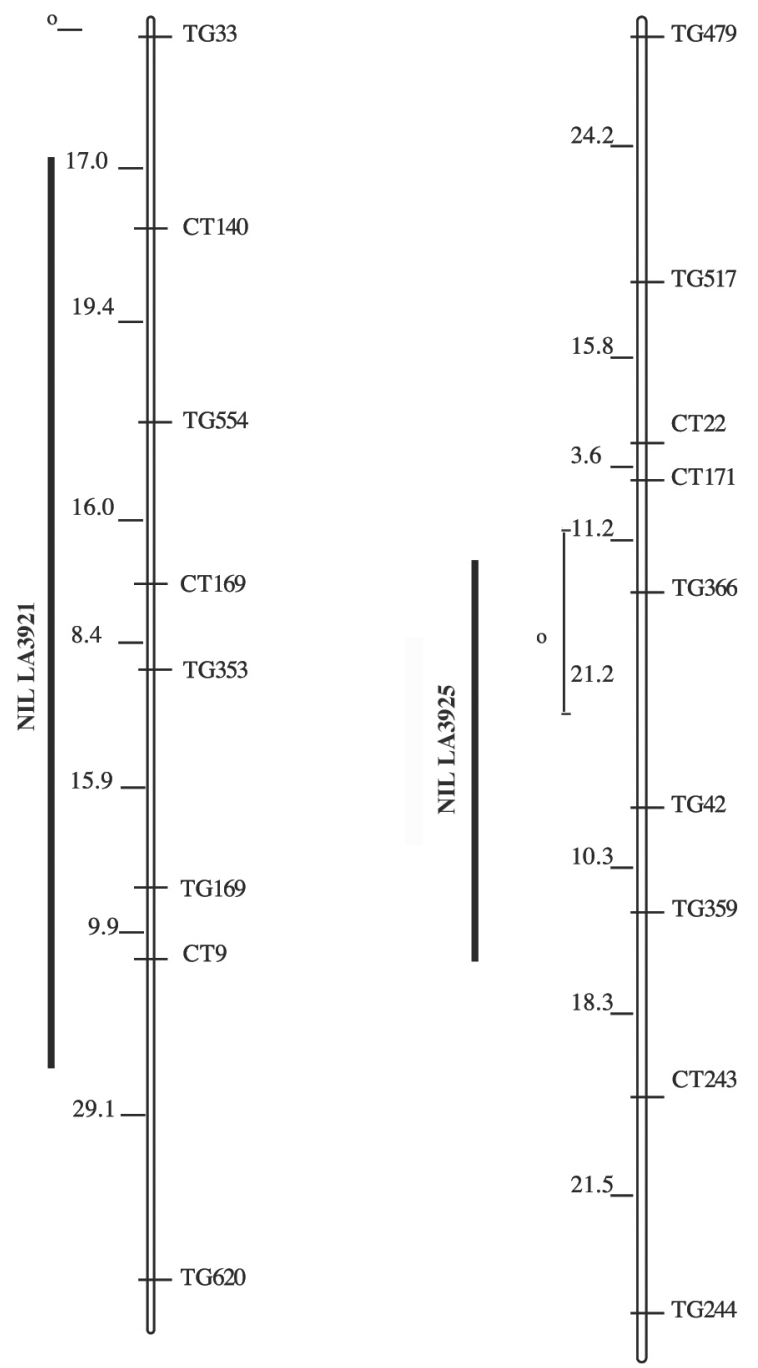

Figure 1. Genetic maps of the nearly isogenic lines (NILs) 2 (LA) and 3 (LA). The introgressions in chromosome 2 and 3 are represented by restriction fragment length polymorphism (RFLP) markers shown on the right. The genetic distance (in $\mathrm{cM}$ ) is shown on the left.

determined considering the accumulation of temperatures below $12{ }^{\circ} \mathrm{C}$ according to records from 2002 through 2006 (unpublished data). The period from seeding to transplanting was $45 \mathrm{~d}$ for the establishment date of August 21; $40 \mathrm{~d}$ for September; $35 \mathrm{~d}$ for September 15; and $30 \mathrm{~d}$ for October 2. A randomized complete block design was used, considering the position in the bed as the factor to distribute the blocks (due to the weight of the plants on the tape). The experimental unit was a $9 \mathrm{~m}^{2}$ plot with 20 plants in a single row. Five blocks were used, each with three rows spaced $1.5 \mathrm{~m}$ apart. The rows were $34 \mathrm{~m}$ long, with $2 \mathrm{~m}$ borders at each end. Each planting date 
was analyzed as an independent experiment. Data were analyzed using ANOVA followed by Dunnett's test with a 95\% confidence interval.

Temperature and radiation data were obtained from an automatic Lufft Opus II (Lufft, Fellbach, Germany) meteorological station, programmed to $\log$ data every hour. Growing degree hours $(\mathrm{GDH})$ were calculated as follows: $\Sigma \mathrm{GDH}=$ current temperature $-12{ }^{\circ} \mathrm{C}$ (the growth threshold for the species). Chilling hours (below $12{ }^{\circ} \mathrm{C}$ ) were also calculated. Radiation was recorded for each hour in units of $\mathrm{W} \mathrm{m}^{-2}$ and interpreted as an integer of accumulated radiation in $\mathrm{MJ}$.

The evaluation of the canopy projection area, as a vegetative parameter, was determined by analyzing digital photographs of three plants per plot at 2, 10 and $20 \mathrm{~d}$ posttransplant, a period in which it was possible to identify individual plants. The area of canopy projection was measured using a pattern in a $150-\mathrm{cm}$ photograph (Figure 2) with the image analyzer Sigma Pro Image Analysis V.5.0 (Systat Software, Richmond, California, USA). The daily increase in the area of canopy projection for the periods from days 2 to 10 and 10 to 20 post-transplant was calculated using the following formula: (final area - initial area)/duration of the period.

Evaluation of reproductive aspects: A flower census was conducted to evaluate: (i) days from planting to the beginning of anthesis in the first truss of the main axis; (ii) number of flowers in the first truss of the main axis; (iii)

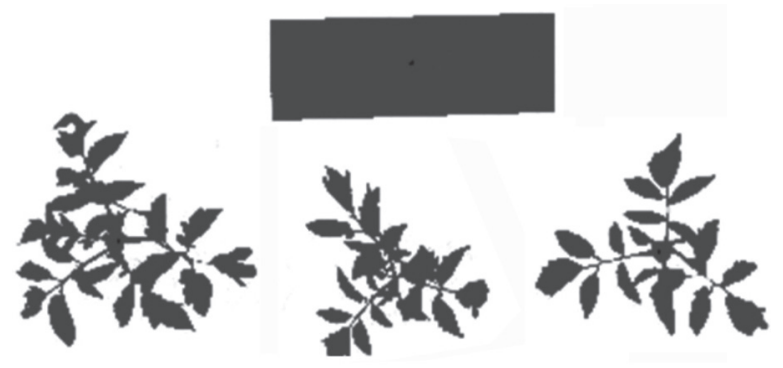

Figure 2. Example of the processed image from the image analyzer along with the standard $150 \mathrm{~cm}^{2}$ area. actual fruit set on the first truss, based on the harvested fruit and the number of flowers that reached anthesis; (iv) days from planting to the beginning of harvest (first red fruit on the European scale of 1 to 8); and (v) number and weight of fruit obtained in each plot, until completion of the harvest from the third truss of the main axis.

\section{RESULTS AND DISCUSSION}

The canopy area can be successfully used to quantify vegetative growth without altering the structure of the plant (Table 1). Both NILs recovered faster than the isogenic control $(\mathrm{p}<0.05)$ on the transplanting date of September 15 , after accumulating $1532 \mathrm{GDH}_{12}$ (Table 1). Both NILs grew 1.7 times more than the control in the period from 2 to $10 \mathrm{~d}$ post-transplant. For the second period considered, between 10 and 20 d, LA3925 and LA3921 grew 1.3 and 1.5 times more than the control, respectively. However, the fruit set on the first truss (Table 2) was 13 times lower in LA3921 than in the control on the same planting date, and was 6.4 times lower on the September 1 planting, with an accumulation of $1217 \mathrm{GDH}_{12}$. The yield (Table 3) until completion of harvest from the third truss of the main axis was not different between the NILs and the control. This could be because the fruit set from trusses 2 and 3 compensated for this initial fruit loss. The low level of fruit set on truss 1 of line LA 3921 can be interpreted as the result of competition between vegetative and reproductive growth. In this respect Heuvelink (2005) indicated that growth and development occur simultaneously, but not in strict correlation. Thus, two plants can have the same number of leaves but display different leaf areas, or have fruit of the same weight but in different stages of maturity. No differences between the lines were presented in terms of plant height or earliness, for any of the transplanting dates $(\mathrm{p}<0.05)$.

Previous research has demonstrated that temperature and radiation are the main climatic factors controlling changes in growth rate and development. High day and low night temperatures result in young plants developing

Table 1. Average increase in canopy growth rate during two evaluation periods, 2-10 and 10-20 d post-transplant (dpt) for four transplanting dates.

\begin{tabular}{|c|c|c|c|c|c|c|c|c|}
\hline \multirow[b]{3}{*}{ Line } & \multicolumn{8}{|c|}{ Growth rate in function of Julian day $\left(\mathrm{cm}^{2} \mathrm{~d}^{-1}\right)$} \\
\hline & \multicolumn{4}{|c|}{$2-10 \mathrm{dpt}$} & \multicolumn{4}{|c|}{$10-20 \mathrm{dpt}$} \\
\hline & 232 & 243 & 257 & 274 & 232 & 243 & 257 & 274 \\
\hline E 6203 & $2.5 \mathrm{NS}$ & $2.4 \mathrm{NS}$ & 5.1 & $5.2 \mathrm{NS}$ & 8.2NS & $9.6 \mathrm{NS}$ & 9.4 & $15.3 \mathrm{NS}$ \\
\hline LA3921 & 2.2 & 1.4 & $8.8^{*}$ & 6.3 & 7.5 & 6.7 & $11.9^{*}$ & 14.0 \\
\hline LA3925 & 1.8 & 1.5 & $8.7^{*}$ & 6.0 & 7.1 & 7.5 & $14.3^{*}$ & 16.0 \\
\hline
\end{tabular}

*Indicates differences between the line and the control according to Dunnett $(\alpha=0.05)$.

NS: non significant. 
Table 2. Flower number and actual fruit set in first truss on the main axis, for four transplanting dates.

\begin{tabular}{llllllllll}
\hline & \multicolumn{4}{c}{ Number of flowers } & & \multicolumn{4}{c}{ Actual fruit set (maximum 1) } \\
\cline { 2 - 3 } Line & $\mathbf{2 3 2}$ & $\mathbf{2 4 3}$ & $\mathbf{2 5 7}$ & $\mathbf{2 7 4}$ & & $\mathbf{2 3 2}$ & $\mathbf{2 4 3}$ & $\mathbf{2 5 7}$ & $\mathbf{2 7 4}$ \\
\hline E6203 & $5.36 \mathrm{NS}$ & $5.40 \mathrm{NS}$ & $4.51 \mathrm{NS}$ & $5.64 \mathrm{NS}$ & & $0.244 \mathrm{NS}$ & 0.320 & 0.530 & $0.150 \mathrm{NS}$ \\
LA3921 & 5.46 & 5.11 & 4.80 & 5.66 & & 0.016 & $0.050^{*}$ & $0.040^{*}$ & 0.100 \\
LA3925 & 3.88 & 4.93 & 4.51 & 5.23 & & 0.278 & 0.140 & 0.538 & 0.222 \\
\hline
\end{tabular}

"Indicates differences between the line and the control according to Dunnett $(\alpha=0.05)$.

NS: non significant.

Table 3. Yield per plant for four transplanting dates.

\begin{tabular}{lllll}
\hline & \multicolumn{4}{c}{ Yield $\left(\mathbf{k g ~ p l a n t}^{-1}\right)$} \\
\cline { 2 - 5 } Line & \multicolumn{4}{c}{ Establishment date (Julian day) } \\
\cline { 2 - 5 } & $\mathbf{2 3 2}$ & $\mathbf{2 4 3}$ & $\mathbf{2 5 7}$ & $\mathbf{2 7 4}$ \\
\hline E6203 & $1.8 \mathrm{NS}$ & $2.6 \mathrm{NS}$ & $5.2 \mathrm{NS}$ & $4.6 \mathrm{NS}$ \\
LA3921 & 1.6 & 2.1 & 4.7 & 4.3 \\
LA3925 & 1.9 & 2.5 & 5.1 & 4.6 \\
\hline
\end{tabular}

NS: non significant $(\mathrm{P}>0.05)$ in the columns.

larger leaf area and thus increasing their interception of light, which in turn maximizes growth (De Koning, 1988). In this experiment, a larger leaf area was observed in the later planting dates, when the daily mean temperature was progressively higher. However, the influence of radiation on growth can alter the response to temperature. Higher temperatures increase leaf expansion rate, except in conditions of low luminosity (Heuvelink, 2005). Figure 3 presents the climatic conditions during the first 20 days after each transplant date.

The period from August 21 to 31 had the lowest accumulated temperature and radiation. The transplanting dates of September 1 and 15 (Julian days 243 and 257) had very similar $\mathrm{GDH}_{12}$ values, with a difference of only two $\mathrm{GDH}_{12}$.

In the first 10 days after September 15, both NILs presented higher growth rates than did the control (Table 1). Upon analyzing the relationship between radiation and growing degree hours for the first 20 days after the establishment dates (August 21, September 1, and October 2), temperature $\left(\mathrm{GDH}_{12}\right)$ presents a linear relationship with accumulated radiation (MJ), which was lowest on September 1. The September 15 planting was different, as the accumulated radiation between the two periods was 1.09 times greater, but the thermal accumulation was 1.15 times lower. The heat sum of temperatures below $12{ }^{\circ} \mathrm{C}$ was variable in the different periods, decreasing towards the establishment date of October 2. It is interesting to note that although the first two dates registered almost double the cold accumulation of the last two dates, the cold resistance genes were not expressed phenotypically. In the first 20 days after September 15, three times more heat accumulation was registered than cold, while it was four times more for October 2, and only 0.5 times more for September 1. Despite these variations in chilling hours and heat sum, no differences were observed between the control and the NILs in terms of vegetative growth (Table 1).

The inverse relationship between $\mathrm{GDH}_{12}$ and radiation found at the establishment date of day 257 (Figure 3) could explain why the NILs presented a $72 \%$ higher growth rate than that of the control, given that genetic expression could be influenced by the combined effect of radiation and temperature. Heuvelink (1989) indicates that in young plants, temperature controls the relative growth rate (RGR) of leaves, by acting on the leaf area ratio (LAR) (leaf area of a plant by its dry weight unit, $\mathrm{cm}^{2}$ $\mathrm{g}^{-1}$ ), thus increasing interception of solar radiation. The combination of low radiation and sub-optimal temperature was studied by $\mathrm{Hu}$ et al. (2006) with tomato varieties for open- field and greenhouse cultivation. Plants with 3 to 14 true leaves were exposed to cold stress, obtaining higher values of net photosynthesis in the greenhouse varieties; the authors point out that greenhouse varieties are cultivated in cold seasons with low luminosity, which allows them to recover from stress. The NILs used in this experiment have cold-resistant genes in the introgressions that are shown in Figure 1, and their recurrent parent is an inbred used to form hybrids for open- field cultivars; however, these NILs expressed resistance depending on the ratio of temperature to radiation. Uzum (2006) found different responses in tomato plant growth before anthesis 


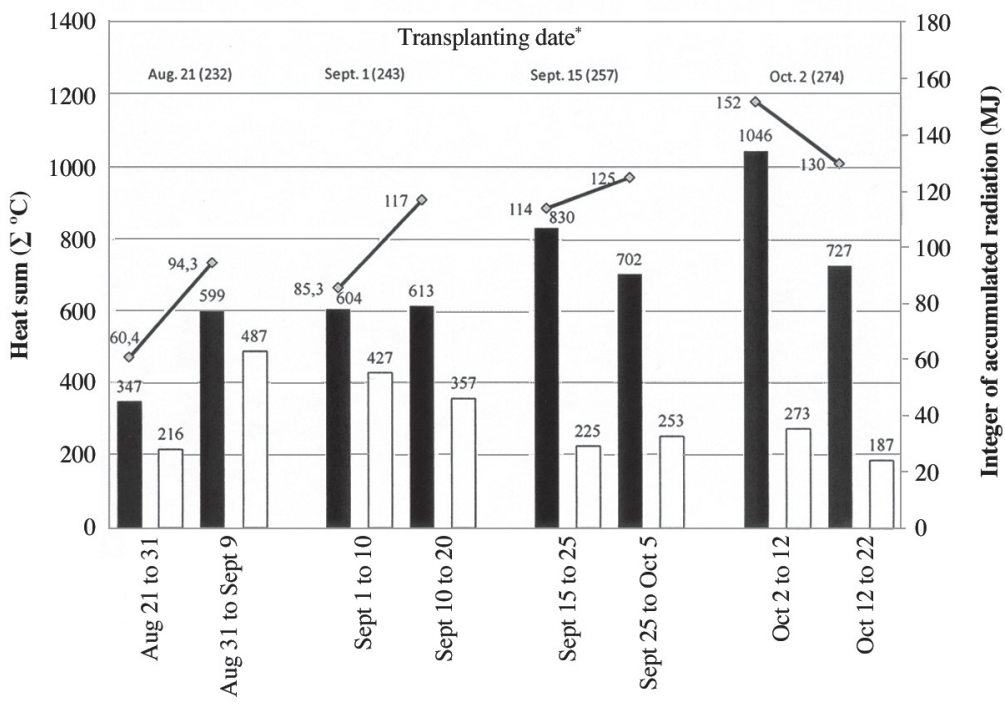

- Heat sum $>12{ }^{\circ} \mathrm{C} ; \square$ Heat sum $<12^{\circ} \mathrm{C} ; \diamond$ Integer of accumulated radiation

*Parentheses indicate the Julian day corresponding to each date.

Figure 3. Environmental conditions during the course of experiment. Each group of four bars represents a single planting date.

of the first truss, under different combinations of radiation and temperature, with a higher number of leaves formed under the first truss under higher radiation, an effect that gradually decreased as the temperature decreased.

In wild species or ecotypes with cold-resistance, this trait is expressed after exposing the plants to sub-optimal temperatures (Venema et al, 2000; Hu et al, 2006). In the natural habitat of $S$. habrochaites, night time temperatures are often below $10^{\circ} \mathrm{C}$. When transplants are subjected to a regime of daytime temperatures of $20^{\circ} \mathrm{C}$ and near freezing temperatures at night, only $S$. habrochaites LA1363 succeeded in forming leaves, while S. lycopersicum did not (Patterson, 1988).

Line LA3921 had an actual fruit set $84 \%$ lower than the control for the day 243 transplanting date, and 92\% lower for day 257 (Table 2). There were no differences $(\mathrm{p}<0.05)$ in the number of flowers per truss and in yield (Tables 2 and 3). This clearly indicates a poor agronomic performance compared to the inbredE6203. Introgression in genomic regions to transfer desired traits from wild species to cultivated tomatoes also passes undesirable genes. This is termed linkage drag and can negatively affect fruit quality and yield (Bernacchi et al., 1998; Tadmor et al., 2002). To eliminate the undesirable traits, the size of the introgression has to be shortened, which is done through backcrosses and marker assisted selection (Hospital, 2001). According to Monforte and Tanksley (2000), the new allelic combination arising after introgression may cause the appearance of new traits- altering leaf morphology (changes in the number and size of leaflets), growth rate and flowering time. This could explain the poor agronomic performance of the NILs compared to the control in this experiment.

The NIL LA3921 at the day 257 transplanting date showed a low fruit set on the first truss, with no difference $(\mathrm{p}<0.05)$ in the number of flowers compared to the isogenic control (Table 2). Although not measured in this work, it has been reported that the tomato is affected by a decrease in the viability of pollen when exposed to temperatures lower than $12^{\circ} \mathrm{C}$ (Picken, 1984). The low light intensity could have reduced the size of flowers and ovaries and halted ovule development (Heuvelink, 2005). Fruit set is a polygenic trait (Catalá and Nuez, 1990) with low heritability (Kemp, 1964), in which there is a high level of interaction with environmental conditions. It was not possible in this study to isolate the QTL in a smaller introgression, which would have allowed for differentiating a pleiotropic effect of the QTL from linkage drag. Currently, there are sub-NILs that can be analyzed in future research to determine the possible pleitropic effects of QTLs that confer chilling resistance at fruit set.

Yield increased with each later establishment date (Table 3), with no significant differences $(p>0.05)$ between the lines and the control. This was expected given the decrease in chilling hours that plants were exposed to at the later dates; for each day after the spring equinox (September 22) there is an increase in incident radiation and day length. 
Analyzing the climatic aspects and their influence on growth and development in the E6203 inbred and NILs used in this study, it can inferred that expression of resistance to cold depends on the combination of thermal and luminous conditions. Resistance is expressed as greater growth when accumulated radiation and the heat sum are not proportional to each other. It is thus necessary to explore resistant genes in other places in the genome, to identify QTLs that have greater environmental plasticity.

The parent donor, S. habrochaites accession LA1777, has shown resistance to cold at different phenological stages, from germination to fruit set, in a wide range of environmental conditions (Patterson, 1988; Venema et al, 2000). This is because the species can be found at different altitudes from 0 to more than $3000 \mathrm{~m}$, as the accession LA1777 comes from a mountainous ecosystem.

A recessive QTL that increases the accumulation of dry matter during cold stress was identified in NIL LA3921, while a dominant QTL was identified in NIL LA3925 for the same trait (Oyanedel, 2000). The methodology used to identify QTLs, both in a $\mathrm{BC}_{2} \mathrm{~S}_{4}$ population and in NILs, was useful in detecting QTLs with dominant and recessive action. The NILs present a high degree of homozygosis, which facilitates the phenotypic expression of recessive QTLs. The present study did not measure the dry matter of plants, opting for a non-destructive assessment of leaf development, which allows for maintaining the crop until harvest. In previous studies, dry matter was quantified under controlled conditions (Oyanedel, 2000). According to Oyanedel et al., 2001, this is an important difference identified in the NILs. Dry matter accumulation is a good indicator of chilling tolerance and can be associated with photosynthetic capacity.

\section{CONCLUSION}

These NILs would have limited utility for developing commercial varieties, given that there is linkage drag of negative traits from the wild parent donor, making it necessary to obtain sub-NILs. In this way, it would be possible to shorten the introgression, eliminating the undesirable genes that negatively affect productivity. Because of the interaction between genotype and environment, it will be necessary to study cold resistance in a sub-NIL population, repeating the experiment in more than one season and using different establishment dates to test crop performance under different temperature to light ratios. Creating and experimenting with a sub-NIL population would help to clarify the real impact of the transference of these QTLs.

\section{ACKNOWLEDGEMENTS}

FONDECYT Project 1040687. We are grateful to Mary Hopkins, Gabriela Verdugo and Eduardo Salgado for critical reading of the manuscript. We are also grateful to Rodrigo Iturrieta for the use of image analysis software and Javier Tapia for his collaboration in collecting data and maintaining the crop.

\section{RESUMEN}

Caracterización de la tolerancia al frío en tomate dependiente de las condiciones de luz y temperatura. La resistencia al frío es una característica deseable en cultivares de tomate, entre otras razones para ampliar el período de cultivo y la distribución geográfica. Se evaluaron dos líneas casi isogénicas de tomate, LA3921 y LA 3925 con introgresiones de Solanum habrochaites S. Knapp \& D.M. Spooner (especie resistente al frío). Las introgresiones se ubican en los cromosomas 2 y 3. Se establecieron cuatro fechas al aire libre, entre el día juliano 232 y 274 (21 de agosto al 2 de octubre). Se analizó el clima en los períodos evaluados, considerando la suma térmica como horas grados de crecimiento en base $12{ }^{\circ} \mathrm{C}$ y horas-frío (bajo $12{ }^{\circ} \mathrm{C}$ ); la radiación se interpretó como integral de radiación. Se evaluó la tasa de crecimiento relativa en dos períodos sucesivos de $10 \mathrm{~d}$ postrasplante, el porcentaje de cuaja y rendimiento. La resistencia al frío se expresó con bajas temperaturas y alta radiación. Esto ocurrió en la fecha de establecimiento del día juliano 257; en el período postrasplante al día 10, ambas NILs presentaron una tasa de crecimiento en área foliar 1,7 veces más alta que el control. Para el segundo período considerado, entre $10 \mathrm{y}$ $20 \mathrm{~d}$ postrasplante, ambas NILs crecieron en promedio 1,4 veces más que el control. No hubo diferencias en la precocidad de cosecha, ni en el porcentaje de cuaja. Estas NILs no podrían usarse directamente para obtener resistencia al frío, debido a una baja cuaja de frutos, 84\% inferior en LA3921, probablemente causada por un arrastre por ligamiento y por una baja plasticidad ambiental de ambas.

Palabras clave: arrastre por ligamiento, Solanum habrochaites, NILs.

\section{LITERATURE CITED}

Adams, S., K. Cockshull, and C. Cave. 2001. Effect of temperature on the growth and development of tomato fruits. Annals of Botany 88:1-9. 
Bernacchi, D., T. Beck-Bunn, Y. Eshed, J. Lopez, V. Petiard, J. Uhlig, et al. 1998. Advanced backcross QTL analysis in tomato. I. Identification of QTLs for traits of agronomic importance from Lycopersicon hirsutum. Theoretical and Applied Genetics 97:318:379.

Bloom, A., L. Brandall, P. Meyerhof, and D. St. Clair. 1998. The chilling sensitivity of root ammonium influx in a cultivated and wild tomato. Plant Cell and Environment 21:191-199.

Bloom, A., M. Zwieniecki, J. Passioura, L. Randall, N. Holbrook, and D. St. Clair. 2004. Water relations under root chilling in a sensitive and tolerant tomato species. Plant Cell and Environment 27:971-979.

Brüggemann, W., and P. Linger. 1994. Long term chilling of young tomato plants under low light. IV. Differential responses of chlorophyll fluorescence quenching coefficients in Lycopersicon species of different chilling sensitivity. Plant and Cell Physiology 35:585591.

Catalá, M., and F. Nuez. 1990. Tomato fruit set under low temperatures. Acta Horticulturae 287:171-178

De Koning, A. 1988. The effect of different day/night temperature regimes on growth, development and yield of glasshouse tomatoes. Journal of Horticultural Science 63:465-471.

Foolad, M., and G. Lin. 2000. Relationship between cold tolerance during seed germination and vegetative growth in tomato: Germplasm evaluation. Journal of the American Society for Horticultural Science 125: 679-683.

Goodstal, F., G. Kohler, L. Randall, A. Bloom, and D. St. Clair. 2005. A major QTL introgressed from wild Lycopersicon hirsutum confers chilling tolerance to cultivated tomato (Lycopersicon esculentum). Theoretical and Applied Genetics 111:898-905.

Grandillo, S., and S. Tanksley. 1996. Genetic analysis of RFLPs, GATA microsatellites and RAPDs in a cross between $L$. esculentum and L. pimpinelifolium. Theoretical and Applied Genetics 92:957-965.

Heuvelink, E. 1989. Influence of day and night temperature on the growth of young tomato plants. Scientia Horticulturae 38:11-22.

Heuvelink, E. 2005. Developmental processes. p. 53-83. In E. Heuvelink (ed.) Tomatoes. CABI Publishing, Wallingford, UK.

Hospital, F. 2001. Size of donor chromosome segments around introgressed loci and reduction of linkage drag in marker-assisted backcross programs. Genetics 158:1363-1379.
Hu, W.H, Y.D. Zhou, Y.S. Du, X.J. Xia, and J.Q. Yu. 2006. Differential response of photosynthesis in greenhouse and field ecotypes of tomato to long-term chilling under low light. Journal of Plant Physiology 163:1238-1246.

Jones, T., D. Tucker, and D. Ort. 1998. Chilling delays circadian pattern of sucrose phosphate synthase and nitrate reductase activity in tomato. Plant Physiology 118:149-158.

Kemp, G. 1964. Inheritance of fruit set at low temperature in tomatoes. American Society for Horticultural Science 86:565-568.

Monforte, A., and S. Tanksley. 2000. Development of a set of nearly isogenic and backcross recombinant inbred lines containing most of the Lycopersicon hirsutum genome in a L. esculentum genetic background: A tool for gene mapping and gene discovery. Genome 43:803-813.

Oyanedel, E. 2000. Quantitative trait loci analysis of chilling tolerance in tomato. 140 p. Thesis Ph.D. Cornell University, New York, USA.

Oyanedel, E., D. Wolfe, A. Monforte, and S. Tanksley. 2001. Using Lycopersicon hirsutum as a source of cold tolerance in processing tomato breeding. Acta Horticulturae 542:387-391.

Patterson, B. 1988. Genes for cold resistance from wild tomatoes. HortScience 3:794-795.

Picken, A. 1984. A review of pollination and fruit set in tomato (Lycopersicon esculentum Mill.) Journal of Horticultural Science 59:1-13.

Tadmor, Y., E. Fridman, A. Gur, O. Larkov, E. Lastochkin, et al. 2002. Identification of malodorous, a wild species allele affecting tomato aroma that was selected against during domestication. Journal of Agricultural and Food Chemistry 50:2005-2009.

Uzum, S. 2006. The quantitative effects of temperature and light on the number of leaves preceding the first fruiting inflorescence on the stem of tomato (Lycopersicon esculentum Mill.) and aubergine (Solanum melongena). Scientia Horticulturae 109:142-146.

Venema, J., L. Villerius, and P. Van Hasselt. 2000. Effect of acclimation to suboptimal temperature on chilling induced photodamage: Comparison between a domestic and a high altitude wild Lycopersicon species. Plant Science 152:153-163. 